\title{
The Political Economy of Makerere Reforms via a Qualitative Approach
}

An Interview with Professor Ruth Mukama

\section{Olivier Provini}

\section{OpenEdition}

\section{Journals}

Electronic version

URL: https://journals.openedition.org/eastafrica/357

DOI: 10.4000/eastafrica.357

ISSN: 2790-1076

\section{Publisher}

IFRA - Institut Français de Recherche en Afrique

Printed version

Date of publication: 1 September 2014

Number of pages: 143-160

ISSN: 2071-7245

\section{Electronic reference}

Olivier Provini, "The Political Economy of Makerere Reforms via a Qualitative Approach", Les Cahiers d'Afrique de l'Est / The East African Review [Online], 49 | 2014, Online since 07 May 2019, connection on 09 December 2021. URL: http://journals.openedition.org/eastafrica/357 ; DOI: https://doi.org/ 10.4000/eastafrica.357 


\title{
The Political Economy of Makerere Reforms via a Qualitative Approach. An Interview with Professor Ruth Mukama
}

\author{
Olivier Provini ${ }^{1}$
}

\section{Introduction}

Compared with the national universities of the neighbouring countries of Tanzania and Kenya, whose recent transformations have not been studied much until now, Makerere University has generated a wide range of scientific research and consultancies in the past decade (Bisaso, 2010; Court, 1999; Kasozi, 2000 \& 2009; Kiiza, 1997; Mamdani, 2007; Musisi, 2002; Sicherman, 2005). The famous and historical Ugandan institution of higher education situated in Kampala was the first university in the East African region to reorganize its financial system and governance starting from the 1990s, and scholars have explored what can be called its "success story" as a privately sponsored institution through "the transfer of model" from the North to the South (Darbon, 2009). This "success story" was built in the 1990-2000s when Makerere was established as a "good model" of the achievement of higher education privatization process in Africa by international organizations, especially the World Bank (World Bank, 2001; Court, 1999). This model was to be followed in driving reforms in the region. Thus, at the meso-level (Marchesnay \& Morvan, 1979), a regional area was put in place in which the "good practices" built and identified, by donors and international organizations, could spread in East Africa (Maupeu, 2012: 198-199).

Makerere has a notable trajectory in the scientific and consultancy corpus on East African higher education. The transfer of models used in the North to introduce privatization in the system of higher education resulted from collaboration between seven American foundations through the Partnership for Higher Education in Africa (PHEA)

1 Olivier Provini is a PhD student in political science under the co-direction of Christian Thibon and Hervé Maupeu (University of Pau, LAM and IFRA). His thesis is about higher education policy transfers in East Africa (Makerere University, the University of Nairobi, the University of Dar es Salaam and the University of Burundi).

I would like to thank Ruth Mukama for this interview, for her agreement to edit it and her scientific support of my research. I am also thankful to Marie-Aude Fouéré who has provided scientific feedback, constructive comments and advices during the writing process. 
launched in $2000 .^{2}$ These foundations pledged to invest $\$ 100$ million in African higher education over five years and to devote their support to the institutional revitalization of selected universities, mostly in East Africa. The PHEA began academic and financial audits to guide the policy-maki ng process. Its results were edited in several case study publications (Musisi, 2003). Undeniably, such a "success story" need to be scrutinized and questioned by scholars in order to unveil how it was built and give insight into the real workings of Makerere University today.

Makerere University, first established as a vocational school in 1922, was principally conceived as an institution for Britain's East African colonies (Sicherman, 2005: 19-38). The first attempts at reforming this elitist colonial institution took place at the time of independence in 1962. Discussions focused on two main issues: i) the need to Africanise the academic staff and ii) the relevance of teaching curricula. However, major reforms came after the NRM (National Resistance Movement) government came to power in 1986. At that time, debates centred on reforming both university finances and university governance. All transformations from the end of the 1980s until the 2000s were shaped during this first phase (Mamdani, 2007: 1-6), especially the implementation of the costsharing policy. ${ }^{3}$

For this short publication, the reforms and transformations of the historical Ugandan public university of Makerere are approached through the presentation of the excerpt of an interview. The interview took place in November 12th 2012 with Ruth Mukama, in her office at Makerere University. Ruth Mukama is a professor of Linguistics. She obtained her qualifications in English language and history from the University of East Africa and in general linguistics from the University of York in England. She started her career as a lecturer at the University of Zambia. She went on lecturing at the University of Dar es Salaam and the University of Botswana before returning home when the Idi Amin Dada regime fell in 1979. Between 1986 and 1991 she was the head of the Languages Department, and between 1991 and 1995 she was the Dean of the Faculty of Arts. She later held various leadership positions as a member of the Senate and Council at the university. She wrote and edited two books about the challenges faced by the social sciences in the twentyfirst century, contending that adopting an interdisciplinary approach can be a solution to save humanities from disappearance (Mukama, $2000 \& 2005$ ). She is also renowned for her passion to promote gender equality and women's empowerment. As the first female Dean in Makerere University, she was even a founder member of Action for Development

2 The PHEA gathers Carnegie Corporation of New York, the Ford Foundation, the John D. and Catherine T. MacArthur Foundation, the Rockefeller Foundation, the William and Flora Hewlett Foundation, the Andrew W. Mellon Foundation and the Kresge Foundation.

3 The cost-sharing in higher education can be defined as "a shift in the burden of higher education costs from being borne exclusively or predominantly by government, or taxpayers, to being shared with parents and students" (Johnstone, 2003: 351). 
(ACFODE), one of the Ugandan pioneer developmental women NGOs, founder members of the School of Women and Gender Studies and the Gender-mainstreaming Directorate of Makerere University.

I argue that Ruth Mukama's point of view on institutional reforms is an original, relevant and valuable angle for the researcher to approach what I call the political economy (Hibou, 2011: 10) of Makerere University's reform policies. Indeed, the interview brings to light several aspects of these transformations: the implementation of the cost-sharing policy; transfer of private funds between the Central Administration and the academic units; the staff management question (recruitment and regulation between the part-time and full-time lecturers); university research and increase of consultancy projects; and staff generational change. As a former Head of a Department, Dean and member of the Senate and Council, she has a singular position in the Makerere academic space (Bourdieu, 1991). Her critical position on reforms implemented asserted in this interview is the result of her experience in these former academic and administrative positions. She was a witness of the shift in state and university management policies: from a university which was a strategic higher education institution for the new independent Ugandan state with staff training and scholarships for all students, established to train a cohort of loyal cadres serving national goals and committed to the notion of public service in a context of nation building, to a university affected by several financial crises that gradually prompted the leadership of Makerere to break away from total dependency on government funding.

Above all, I contend that the interview reveals the centrality of the struggle over resources between the different elements (Central Administration, Faculties, Department, staff) comprising the university, especially the internally generated funds. How have efforts to control resources become a key element to understand Makerere reforms between the 1980s and the 2000s? Why and how is resource regulation narrowly linked with management reforms? Ruth Mukama gives us comprehensive elements to answer these questions through a political economy perspective on Makerere reforms. She argues that the last management reforms, which were due to bring increasing autonomy to academic units, simply do not work because the budgetary transfer from the central administration to these units is partial. The funds generated by income-generating units, principally through the introduction of private students, are mainly centralised by the top administration. She notices an incomplete transfer of power whereby new university structures, called the Colleges, do not have enough resources to make use of their prerogatives. Such prerogatives essentially concern staff recruitment and academic research, today in a precarious situation. More generally this new configuration fundamentally questions the position of social sciences in a context where the government allocates in priority research grants and student scholarships for science (Republic of Uganda, 1998, 2004 \& 2013). 


\section{The interview}

Olivier Provini: You have been a lecturer and professor since the 1980s so you have a long experience at Makerere University and you have seen the many transformations that took place therein. For instance, a major transformation is the introduction of private students in the mid-1990s. What can you tell me about the evolution of your teaching conditions since the 1980s, and the impact of the implementation of the policy of private students?

Ruth Mukama: There were very few changes in our conditions. If there is anything, it is worse and worse because the teachers still do not have enough in their hands for their needs. It is always much less, much less. The higher the inflation goes, the less you have with our insufficient salaries. They have always been very inadequate. And yet, working conditions are getting worse also. Because, at first, we had few students and, you know, we could give them better quality education and, for instance, we could even give tutorials. The classes were manageable, we could give some seminars, but when the number of students increases, if you have tutorials, how many [can you have]? Now we started just lecturing. You cannot afford to start giving tutorials because you will be teaching all the time and it still won't be enough. You do not have any time to go home because students are just too many. So the working conditions are becoming hard, salaries are inadequate, which means you have to get consultancies and other means of getting enough to sustain yourself. This has inevitably affected the quality of teaching because if I am completing a consultancy, it means I am worried about finishing somebody's work before they pay me, and definitively I will give less to my teaching. I will not mark my assignments in time because I have to do other things to survive, so life is very hard, the conditions are worse, and, yet, the numbers [of students] is increasing (...). The government does not listen to our requests of salary increases, and even the funding of the university becomes much less, you know, the conditions are much harder. Even the teaching facilities are not good, we need modern gadgets like a projector or new computer programmes, but the majority of us do not have a computer. So many of the students do not have access to computer and you cannot even use the computer technology. So all these services, we do not have. And the library is also poorer, they do not have enough money to order new books so even books are not updated, the library cannot order the most current books. So if you go to the library, you will find very old books and many of them have even been stolen! Because students fight for one copy and eventually they tear pages out an, eventually, the whole book vanishes. So the situation is really getting worse. That is why I get surprised when it is said that teachers are in sufficient numbers; I do not know what they are counting! The staffing structure is bottom-heavy; with limited numbers of senior members of staff, especially at professorial ranks. The younger lecturers, who are the majority, are in a state of deprivation: they want to get good things, but the salaries are not enough, they are not paid on time, and many of them are part-time workers. And when they are not paid for a 
whole year, they have to find other places to teach, or other means of getting some money, to be able to continue to be here to teach for nothing. So it is hard and, as a result, when you advise some of them to register for another degree, they do not complete. Some of them can take over ten years to finish their masters, others give up, because they have no time, they cannot even read, they have no access to modern research facilities, because they cannot order scholastic materials. Many of them have no computers so they have to buy their own laptops; that is how they survive. But the university cannot give them students' facilities.

O.P.: And about salary increase for professors, lecturers or assistant-lecturers, the government said that a means to increase it was the introduction of private students because part of these funds will be used to...

R.M.: It was in fact the university. Because when I was Dean, we had the worst conditions. I would sit in the Dean's office alone and teachers were in town teaching, or engaged in some other sources of income in different places, because the conditions were very bad. The salaries were very very low. That is when we said "maybe we have to start admitting private students" so that they pay what the government is not paying. And they still do not pay even what they are supposed to pay, even for the buildings. If the donors did not give some money for the buildings, there would be no new buildings in the university.

O.P.: So it was a means to increase the university budget and staff wages?

R.M.: Exactly. So we said that if the government cannot pay the allowances, then we admit private students and get enough money to increase the staff salaries and also to pay for other facilities that the government cannot. ${ }^{4}$ That is how it started. And as soon as we started getting students, the government completely stopped paying and said: "you are now getting your own money". So even the so-called "government-sponsored students" are sponsored by private students now. The government does not even support what they call the government-sponsored students. And now again the university is in the same situation; no money. Whatever the private students pay is now financing most services: buying chemicals, buying teaching materials, everything! So the government has just given us up, apart form paying the basic salaries. Even the people who were supposed to be sponsored; for instance, in the halls of the residence, the money that comes from private students buys food for government-sponsored students. So again we are back in the area of the 1990s when there was nothing, because now the money from the private students is doing everything and it is not enough. We are in the same situation we were

4 Appendix A "The Makerere Privatization Process, 1995-2005". 
in when I was Dean, because there is no money. Now they have created more structures, ${ }^{5}$ like the colleges, but there is no money to provide for them adequately. Money is not sent to colleges. Colleges are supposed to pay everybody: the part-time staff and full-time and pay allowances. But the Central Administration does not send enough money to enable the colleges to meet their obligations. So conditions are becoming worse and worse. You create structures and you cannot support them and then the Central Administration retains the greater proportion of the money collected because they want to pay themselves more, fly all over, get whatever they want, buy themselves very expensive cars and make themselves generally more comfortable. When the power goes off, they have an automatic generator but ours is manual and has no fuel most of the time; so when the power goes off we often remain in darkness because the money is not sent to us to cater for most of our needs. And yet for the teaching, we depend on part-time staff and we cannot recruit more staff. We have developed very good programmes which are accredited by the National Council for Higher Education, ${ }^{6}$ but we cannot teach them. They remain programmes on paper because the University is not recruiting staff; they stopped recruiting staff a long time ago because they say "we do not have money to pay them, the new staff". So if you are not recruiting, you are not increasing teaching space and yet you are increasing students every year, what is the way forward? You are depending on part-timers who you are not paying; so how can one talk of "quality assurance"? ${ }^{7}$ Because even the Department of the Quality Assurance itself, if you go there you will laugh! Two miserable people there, they cannot work! How can they insure quality? There is no quality assurance even in the quality assurance office itself! So what do expect? Many professors are retained on contract after retirement because there is hardly any recruitment of new staff at that rank. Even staff in mid-career ranks are now retained after retirement and they are even promoted to higher ranks as if they are still in mainstream service!

5 In November 2010, the Makerere University Senate approved a new college structure in which eight colleges were proposed: the college of agriculture and environmental sciences, the college of natural sciences, the college of humanities and social sciences, the college of health sciences, the college of engineering, design, art and technology, the college of computing and information sciences, the college of education and external studies and the college of business and management sciences.

6 The National Council for Higher Education (NCHE) was established by an Act of Parliament in 2001 as a semi-autonomous body to regulate higher education and "guide the establishment of institutions of higher learning as well as ensure the quality and relevant education is delivered". See the website of the Council http://www.unche.or.ug

7 Makerere University is a good example of the growth of a new agenda. We notice the development of neoliberal procedures, especially via the implementation of quality assurance Departments, in East African universities, both public and private. This quiet and shared revolution has great implications in terms of administrative routine, identities of actors, definition and role of a university and, more generally, boundaries between private and public spheres (Provini, 2012). 
O.P.: And what about the role of the MUASA,${ }^{8}$ for instance, in improving the teaching conditions?

R.M.: They have tried. They have gone even to the President many times. But he tells them that he has other priorities! And when they got something, he said he is increasing salaries only for science teachers and science lecturers and technology. So those have a salary increase. And he said "What about humanities and social sciences? Those have..." (She is hesitant). In fact, he does not have any opinion about humanities. As far as he is concerned, they do not exist, what matters are sciences. They have got a better pay, and, for us, there is nothing! And yet they have also better research facilities because many donors also fund sciences and technologies. And our staffs are demoralized because many of them are only just surviving. They cannot even do research. As I told you, our people do not finish their degrees because they have no time. You find that one lecturer is teaching in ten schools, running here and there every minute, just comes to campus when he has a lecture and then runs off soon after, going elsewhere to teach. And you cannot blame them because they have to pay for their accommodation, which is very expensive, and they have to stay in Kampala and sometimes they have to pay their rent six months in advance and if you do not pay, you have nowhere to sleep, you have nowhere to work, where will you go? So they have to work in different places to get money.

O.P.: You said there are some tensions between the Central Administration and the academic units to control the money generated by the private students. ${ }^{9}$ What do you think of the fact that the top administrators say that they try to implement a decentralisation process, for instance, with the implementation of the new structure of colleges, what do you think about it?

R.M.: They talk about decentralisation but they do not decentralise. Take the example of the case of my colleague, professor O. Ndoleriire, ${ }^{10}$ who was a member the former Institute of Languages before he was appointed Acting Principal of the College of Humanities and Social Sciences; when he moved to what they called the College Principal's office, he had to take Institute computer because there was none in his big office. He even took the Institute secretary because there was no secretary in the college office and he took all other supplies from the Institute to start off the theoretically elevated office. And we

8 The MUASA, Makerere University Academic Association, organizes the defence of staff's interests, especially to increase their wages. For instance, in April 2013, the new MUASA chairperson, Dr. Kiggundu Musoke, explained that the association was seeking a payrise of 100\% (Ssenyonga, 2013).

9 Appendix B "Evolution of the Fee Distribution Between the Academic Units and the Central Administration, 1992-2012".

10 Oswald Ndoleriire is the current principal of the college of humanities (since January 2011) and social sciences and professor of linguistic in Makerere University. He was associate dean and dean of the Faculty of arts (from 1989-2003), Director of the Makerere Institute of languages (2008-2011). He was also country Director of the African Institute for Capacity Development (AICAD, from 2002-2010). 
wondered aloud: "What? You are Principal, you should get these things!" It took almost a year to make provisions for his new office. So colleges were created without planned budgetary provisions for them. There was more lip-service to the creation of the college structures than level-headed and fore-sighted planning. It is hard to tell whether the college arrangement will work. How do you create structures but not facilitate them? If you keep all the money paid by students, how can you say that the colleges should be independent? How? How could you be independent if you are not allowed to share the fees? The fees are centralised. Even the small percentage which is supposed to be sent to them is sent in tiny quantities and very irregularly. So how do you expect these structures to be selfsustaining and to be able to pay all the part-time staff and other college staff, as well as allowances for the full-time staff when you are not sending them the money? Or if you send, it is a very tiny percentage. So while the structures are decentralized the resources are not; it cannot work. On our part, we continue to teach, and there are no allowances or whatever for us. We used to have coordinator allowances, we do not have anymore. We were supposed to get professional allowances, they were never paid, and they all remained on paper. Whatever payments are supposed to be made are never paid. Of recent, the nonpayment practice has been extended to salaries; I received no salary for three consecutive months and I am not alone.

O.P.: You mentioned something very interesting, about the development of new practices with the increase of consultancies among lecturers and professors. What can you tell me about the increase of these consultancies and what about the university research? Because it is two different things and the development of consultancies can be a problem for scientific research because lecturers and professors might not have time to do scientific research, or they do not have funds to do scientific research. And what is the situation in your specific School of Languages?

R.M.: First, you see, we do not have enough money for research, university research, from the government, ${ }^{11}$ when it comes, it is very little. You know it cannot really service a good well-developed project. So many lecturers and professors who are able to get external consultancies which pay well go for them. You know, that has implications: when you are paid by a bi-lateral partner, an international agency or company, or parastatal body, or NGO, they all have their own conditions and priorities of research. So most of these consultancies, which members of staff, do are in fact private consultancies and they are

11 Appendix C "Makerere Research and Development Budget, 2005-2009”. 
not available [for the University $]^{12}(\ldots)$. And it is also affecting the quality of university teaching. As already noted, those donors give you their own demands and deadlines. And they want you to certify certain conditions and requirements for their research grants. And, for one to attend to all those requirements, one really does not have time for university teaching and research, it is now for one's own survival. It is a way of supplementing your salary. You have to pay yourself to continue teaching for Makerere, because Makerere is unable to pay you enough. So we look for those consultancies to be able to subsidize Makerere, because Makerere is unable to pay us. If one wants to buy a plot somewhere, Makerere cannot give the requisite financial support. If one wants to build a house for oneself, Makerere cannot help financially. If one wants to buy a car, Makerere cannot help, even by way of giving one a loan. So, what does one do? One gets a consultancy, which will yield some extra income, then one can continue to do work for Makerere and you say that you are a member of staff of Makerere but, actually, you are paying yourself. You have to look for your own supplementary incomes. The consultancies help. But as already mooted, they come with implications; they are just income-generation consultancies. They have nothing to do with improving the quality education. So, really, the quality of education is under threat, great threat! How shall we insure the quality assurance? If you are supposed to teach a new programme but you are alone, what do you do? And for those who spend most of the time in income-generation consultancies, how do they teach? I know some colleagues, at all levels of academic ranks - assistant lecturers to professors that get other people to teach for them. They continue doing their consultancy work to get money to pay their substitute teachers! The university cannot pay those part-time teachers. So I have to finish my consultancy and pay this person to help me to teach this programme. But the problem is also with the supervision because most of these teachers, they are just graduated, they cannot supervise anybody. So it is the supervision now that we have to maintain because we have Master and $\mathrm{PhD}$ students and we are forced to supervise them. But they also suffer as I cannot read their theses because I do not have time to do so! I have to finish that consultancy, I have that deadline! So I cannot start supervision even in postgraduate studies, I am disillusioned because when I do a supervision, then,

12 For instance, Augustus Nuwagaba is an associate professor of social works, population and poverty in the Department of social work and social administration at Makerere University. He also works as the Managing Consultant at REEV Consult International Limited, a private consultancy firm with headquarters at Wandegeya in Kampala. The REEV Consult offers consultancies in the areas of impact assessments, planning, social policy analysis, management services and institutional development services. He was also consultant for the Designing the District Development Programme (DDPIII) supported by the United Nations Capital Development Fund (UNCDF) and also consultant for the development of national Integrated Monitoring and Evaluation Systems (NIMES) for all sectors Ministries in Uganda (http://reevconsult.co.ug/about-professor-nuwagaba-. $\mathrm{html}$ ). He also served as the Chairpersoon of Makerere University Academic Staff Association (MUASA) after his studies in London in the 2000s. The March 11th 2012, he joined the race for Makerere University' vicechancellor job (http://www.newvision.co.ug/news/629545-Nuwagaba-joins-race-for-Makerere-VC.html) and was disqualified the August 6th 2012 (http://www.newvision.co.ug/news/633829-Nuwagaba-disqualifiedfrom-Makerere-VC-race.html). 
they pay me 50,000 Ushs ${ }^{13}$ when students are graduated, so how do I survive? I mean, it is ridiculous! The government, the university, they are not serious! You expect these persons read volume and volume of these theses for nothing! They even do not pay if you are internal examiner, they do not pay anything. They only pay a supervisor 50,000 Ushs when that person has graduated. You have struggled with this person for ten years. And sometimes they also disappear because they also have to survive and they cannot pay for the tuition if they are not working in different places because, again, the government says no funding for post-graduate studies, so who funds? You know, it is like a big joke! How do you expect to maintain quality assurance? How do you expect to maintain high standard of education? How? It is the same with teachers in schools. They are not paid, they ask for small increases but the government rejects, they go on strike, the police are send to beat them up, how do you expect them to teach? How do you expect them to do a quality work? So, really, the future of education, especially for humanities, is really under great threat. I do not know what we can do. We had a conference in Nairobi for the East African humanities....

O.P.: When?

R.M.: It was in 2010. It was organised by the Inter-University Council for East Africa. ${ }^{14}$ Last year, we were in Dar es Salaam, for the same conference about humanities. We meet and say: "What shall we do? We should undertake project together. We must find a way of sustaining our discipline but how can we do it?". Even in the Inter-University Council, they do not have enough funding. If these oversight bodies are not funded, so who will fund humanities? There is an American group, which was being funded by the Carnegie Corporation and they were providing post-doctoral grants and also doctoral grants. But now, Carnegie said last year, they cannot continue funding this project. They were trying to help the humanities with these post-doctoral grants, with publications. They helped the humanities to survive. So I think that our main goal is for international cooperation and we find avenues to facilitate research in the humanities and social sciences, because now, if the government, our own government cannot give us research funding, how will this discipline survive? (...).

O.P.: And one of the means to preserve the humanities was the implementation of new courses, more linked with the market. What do you think of this policy in humanities and social sciences?

13 50,000 Ushs worth about 18 US\$.

14 The Inter-University Council for East Africa (IUCEA) is a regional inter-governmental organization established in 1980. It was formerly the Inter-University Committee (IUC), created in 1970, after the dissolution of the University of East Africa. The IUCEA aim is to facilitate contacts between the universities of the East African community, to provide a forum for discussion to maintain high and comparable academic standards. For instance, one of the last forum was held in Arusha on theme of "Linking University to industry for building knowledge-based economics and regional integration in East Africa" (24-26th October 2012). 
R.M.: You see, we are dying and we need to survive (...). Now, we are even going to implement demand-driven courses... we are killing ourselves, ironically. You know I had a colleague, unfortunately she retired last year, and they would not give her a contract. She is a planner in urban planning. When she left, a young person came in and they have these market-driven programmes. Now, they write new programmes: urban planning and management, urban planning and modern things, urban planning and tourism, urban planning and everything, urban planning and...! Then my former colleague was asking: "where is urban planning itself?", you see, and the same thing has come into linguistics. This young person came and wrote programmes, now we have: language and religion, language and editing, language for mass communication, language and...! Ok, you get it, but where is linguistics? You have killed it!

\section{O.P.: Yes, where are the traditional courses?}

R.M.: Exactly! Where is morphology, where is phonology? Now, they have gone in applied things, applied courses, but where is the essence? Because these people, what are they applying? How can we describe the language of religion? We learnt morphology without syntax, we learnt morphology. So, again, our young people say: "We need these attractive courses". We have to attract students, but you attract them to what? They have killed the essence of the courses because they want to implement so-called popular courses. But now, none of the young can teach syntax, none of them can teach semantics. So how many courses can I teach? When I am supervising postgraduate students, when I am supervising teachers who help me to teach, they know nothing! They have done relevant courses, they cannot go there and teach phonology, they cannot teach morphology, they cannot teach semantics, they cannot teach research methodology. They know nothing!

O.P.: This policy of implementing new curricula was initiated firstly by professor O. Ndoleriire when he was the Dean of the Faculty of arts and it was very criticized by professor M. Mamdani in his book on university reforms in Makerere (Mamdani, 2007). What can you tell me about it?

R.M.: Yes, scholars in the marketplace (laughing). As he said effectively in that book, we went into a privatisation and then, now, people went to other extremes. Now, everything we do, it goes to the Central Administration. But at that time, the Central Administration did not start to take our money. So the Faculty, when the professor O. Ndoleriire was the Dean... there was plenty of money in the Faculty because the Central Administration was honouring, they were sending most of the money back to the Faculty. But, when they became more and more greedy, and then they are sending just a little money here, now they reversed what was professor O. Ndoleriire's time. They reversed that, instead of giving the Faculty the majority of what the private students pay. Now the Central 
Administration started retaining more and gives us very little money. And then the Faculty had to continue paying extra-teaching, part-time teaching, all workers here, because there are many, even those post-graduate part-time, and the Central Administration does not pay them. They are taking away the money. That is when professor M. Mamdani started writing. Everybody wanted to teach, the lecturers were fighting to get teaching, to teach even five courses, because of that money. And they wanted to get more and more courses because there was money to pay them. But now it is the opposite. You teach... the more you teach, the less you get, because there is no money, they cannot pay you. And if they pay, it is very little. But during the 1990s you were paid, even for examinations we were paid and people worked very happily. But then they worked, still ironically, they could not do research, because they wanted to teach all the time! (laughing). Still research suffers. So, by the way, research has always suffered. When there was a lot of money, they wanted to work to get that money, again less time for research, in fact no time for research, because you want to do more and more work (...). But now nobody wants to work, nobody wants to teach, because they do not pay. In fact professors are now working on their consultancies to get enough money to pay the people who are teaching their courses. But now, there is also no research for improving the teaching. So it is a terrible situation. So M. Mamdani was very correct when he wrote that book. At first, I was very angry with him. But he did his research... he did that research here. You know, in this university, there is no research project, not even in the Faculty of projects, not even in the Department of projects, there were none. People are very busy to get the money of consultancies. That is why M. Mamdani said now this money-racket has killed the essence of scholarship because still people are not working to improve the teaching. So when he wrote, there were a lot of truth in what he said in that book. So it is ironical. When there was enough money, we were not working, and when there is no money, we are still not working! So when shall we work? It is ironical. It is also linked with values. We want to do a good job (...), and want to do a job of quality. But these people do not have that value, the young ones. They do not have our value. We feel concerned that standards are going lower and lower. We are now in the mediocrity. We get worried, we get concerned but the young ones do not care! They get surprised when you are worried about the work they did. For us, there is no substance in their work and they do not understand. So it is a tragedy, I do not know what future, because the young ones do not have any concerns for the future. It is just like survival for today. They do not care about tomorrow. So I really do not know. I cannot tell you, I do not want to imagine the future of humanities. I think that social sciences are going to die completely. I was in this Pan-African university panel 
for the African Union, they have created this new Pan-African University ${ }^{15}$ but even there I was representing humanities but most of them were scientists and they were just talking about sciences, sciences, sciences! And I said "What about humanities?". They have to survive. So, they just put one centre for humanities, and this is in Yaoundé. So I do not know, the humanities are under a great threat (...). I am in a dilemma. I wrote a beautiful programme for the Department of African languages. So I wrote a programme for teaching African Masters in African languages, a very beautiful programme. The National Council for Higher Education was so impressed by this programme and they made it as an example and gave it to literature, the literature had written a very poor one. They said: "Please, use it as an example to improve your programme". But, ironically, I cannot teach that programme alone. You have one person who can teach that programme. How can you teach it? You cannot (...)! I am alone and the university cannot recruit any other person. So who will assist? So you can write a beautiful programme, it can be accredited, but I am alone (...). We are two professors available, with professor O. Ndoleriire. But professor O. Ndoleriire could not teach anymore when he was Principal. You are always in meetings. What is the usefulness of these meetings? But you have to attend them. Until last year, I was a member of the University Senate, I was also a member of the University Council. Every other day, there is a meeting. There is a Council Committee meeting and I have to be there. As a representative of the Senate and Council, you have to be there, but every other day there is a meeting! When do you teach? They put you in the administration. Until two years ago, I was again taken to the gender mainstreaming division to head it, because the head was becoming the vice-chancellor of Kabale University. So we, the few people who can still work, who know what we are doing, they are always putting you go to places, go and represent. I also used to go to Addis Abeba until last year when we were launching this programme about the Pan-African University. I had to go there and write all these programmes. Those scientists could not write the programmes! The scientists could not write! I did all the work alone because I was the only one who could write English. So I was over-worked and I could not teach. So when do you teach? They made you a full-time administrator (...). Even the President, for two years, he made me head of some projects in Bunyoro Commission of inquiry where I had to listen problem of villagers and I was not teaching in Makerere. I was there as a head of one commission. And he just called you and said "you are the chairperson of the committee, go to Bunyoro". And I was in Bunyoro for two years.

15 The Pan-African University was launched in December 2011 in the Ethiopian capital Addis Ababa, the headquarters of the African Union. The first four institutes of the university are: i) the Western Africa PAU institute of life and earth sciences at the University of Ibadan (Nigeria); ii) the Eastern Africa PAU institute of basic sciences, technology and innovation at the Jomo Kenyatta University of agriculture and technology (Kenya); iii) the Central Africa PAU institute of governance, humanities and social sciences at the University of Yaoundé (Cameroon); iv) and the northern Africa PAU institute of water and energy sciences. 
O.P.: And you do not have the choice.

R.M.: And you do not have the choice! It is a presidential directive! You just go. So, what is the future of education? He even does not warn the vice-chancellor of the university that he is taking me as the head of this commission because he is the President. It is his directive. Has he cared about the programme that I was teaching? Has he cared about the quality? Because I put here a teaching assistant who did not know what to do. He was calling me: "Now what do I do? Because there is this...". I am in the field in Bunyoro but he was calling me because he did not know what to do. So do you think that our government cares about the future of higher education?

\section{Bibliography}

Bisaso, Ronald. "Organisational Responses to Public Sector Reforms in Higher Education in Uganda: A Case Study of Makerere University." Journal of Higher Education Policy and Management 32 (2010): 343-351.

Bourdieu, Pierre. "Le champ littéraire." Actes de la recherche en sciences sociales 89 (1991): 3-46.

Court, David. Financing Higher Education in Africa: Makerere, the Quiet Revolution. Working paper: The World Bank \& The Rockfeller Foundation, 1999.

Darbon, Dominique (dir.). La politique des modèles en Afrique. Simulation, dépolitisation et appropriation. Paris: Karthala \& MSHEA, 2009.

Hibou, Béatrice. Anatomie politique de la domination. Paris: La Découverte, 2011.

Johnstone, Bruce D. "Cost-Sharing in Higher Education: Tuition, Financial Assistance, and Accessibility." Czech Sociological Review 39 (2003): 351-374.

Kasozi, A. B. K. University Education in Uganda. Challenges and Opportunities for Reform. Kampala: Fountain Publishers, 2000.

-Financing Uganda's Public Universities. An obstacle to Serving the Public Good. Kampala: Fountain Publishers, 2009.

Kiiza, Julius. "Liberalisation Policies and University Education in Uganda: An Assessment of the Cost-Sharing Policy." Makerere Political Science Review 1 (1997): 72-87.

Makerere University. Fact Book 2009/2010. Kampala: Makerere University, 2010.

Mamdani, Mahmood. Scholars in the Marketplace: The Dilemmas of Neo-Liberal Reform at Makerere University (1989-2005). Saint-Paul: CODESRIA, 2007. 
Marchesnay, Michel \& Morvan, Yves. "Micro, macro, meso..." Revue d'économie industrielle 8 (1979): 99-103.

Maupeu, Hervé. "Les réformes néolibérales des universités est-africaines: éléments d'analyses à partir du cas kényan." In Universités, universitaires en Afrique de l'Est, ed. Bugwabari, Nicodèle, Cazenave-Piarrot, Alain, Provini, Olivier \& Thibon, Christian, 195211. Paris: Karthala, 2012.

Mukama, Ruth. Challenges to the Social Sciences in the Twenty-First Century. Proceedings of the International Conference Held at the International Conference Centre, Kampala: 25-27th October 2000. Kampala: Makerere University, 2000.

— "The Humanities and Gender Mainstreaming: a Case of Makerere University", not yet published.

Mukama, Ruth \& Rutanga, Murindwa (ed.). Confronting Twenty-First Century Challenges Analyses and Re-Dedications by National and International Scholars. Kampala: Makerere University, 2005.

Musisi, Nakanyike B. "Embryonic Transformation: Makerere University in the 1990's and into the 21 st century." In Transformations in Uganda, ed. Musisi, Nakanyike B. \& Dodge, Cole P., 241-265. Kampala: MISR, 2002.

Musisi, Nakanyike B. \& Muwanga, Nansozi K. Makerere University in Transition 19932000: Opportunities and Challenges. Oxford \& Kampala: James Currey \& Fountain Publishers, 2003.

Provini, Olivier. "Croquis du nouveau management public dans l'espace universitaire estafricain." Mambo! 10(2012).

Republic of Uganda. Vision 2025. Kampala: Republic of Uganda, 1998.

—Education Sector Strategic Plan 2004-2015. Kampala: Republic of Uganda, 2004.

- Science, Technology and Innovation in Uganda. Status Report 2009/2010. Kampala: UNCST, 2011.

—Vision 2040 Draft. Kampala: Republic of Uganda, 2013.

Sicherman, Carol. Becoming an African University. Makerere 1922-2000. Kampala: Fountain Publishers, 2005.

Ssenyonga, Andrew. "Makerere Staff Want 100\% Payrise." New Vision, 6th April 2013.

World Bank. A Chance to Learn. Knowledge and Finance for Education in Sub-Saharan Africa. Washington: World Bank, 2001. 


\section{Appendix A: The Makerere Privatization Process, 1995-2005}

\begin{tabular}{|c|c|c|c|c|c|}
\hline Year & $\begin{array}{l}\text { Government } \\
\text { funding } \\
\text { (US\$) }\end{array}$ & $\begin{array}{l}\text { Internally } \\
\text { generated } \\
\text { funds }{ }^{1} \\
\text { (US\$) }\end{array}$ & $\begin{array}{l}\text { University } \\
\text { budget } \\
\text { (US\$) }\end{array}$ & $\begin{array}{l}\text { Percentage } \\
\text { of the } \\
\text { government } \\
\text { funding } \\
\text { in the } \\
\text { university } \\
\text { budget (\%) }\end{array}$ & $\begin{array}{l}\text { Percentage } \\
\text { of the } \\
\text { internally } \\
\text { generated } \\
\text { funds } \\
\text { in the } \\
\text { university } \\
\text { budget (\%) }\end{array}$ \\
\hline 1995 & $19,786,481$ & $3,971,286$ & $23,757,767$ & 83 & 17 \\
\hline 1996 & $19,813,610$ & $7,280,117$ & $27,093,727$ & 73 & 27 \\
\hline 1997 & $19,612,939$ & $8,201,686$ & $27,814,625$ & 71 & 29 \\
\hline 1998 & $19,023,730$ & $11,110,096$ & $30,133,826$ & 63 & 37 \\
\hline 1999 & $17,210,572$ & $10,369,145$ & $27,579,717$ & 62 & 38 \\
\hline 2000 & $14,336,748$ & $10,743,010$ & $25,079,758$ & 57 & 43 \\
\hline 2001 & $15,831,974$ & $10,939,046$ & $26,771,020$ & 59 & 41 \\
\hline 2002 & $15,912,704$ & $17,017,619$ & $32,930,323$ & 48 & 52 \\
\hline 2003 & $14,449,973$ & $17,344,090$ & $31,794,063$ & 45 & 55 \\
\hline 2004 & $20,282,740$ & $20,702,567$ & $40,985,307$ & 49 & 51 \\
\hline 2005 & $19,779,135$ & $30,196,108$ & $49,975,243$ & 40 & 60 \\
\hline
\end{tabular}

References: Kasozi (2009: 164) ; Court (1999: 5-7) ; Makerere University (2010: 5) 
Appendix B: Evolution of the Fee Distribution between the Academic Units and the Central Administration, 1992-2012

\begin{tabular}{|c|c|c|c|}
\hline Academic year & $\begin{array}{l}\text { Private } \\
\text { students }\end{array}$ & $\begin{array}{l}\text { Academic units } \\
(\%)\end{array}$ & $\begin{array}{c}\text { Central } \\
\text { Administration (\%) }\end{array}$ \\
\hline \multirow[t]{2}{*}{1992} & Day & 70 & 30 \\
\hline & Evening & 90 & 10 \\
\hline \multirow[t]{2}{*}{1993} & Day & 70 & 30 \\
\hline & Evening & 85 & 15 \\
\hline \multirow[t]{2}{*}{1994} & Day & 70 & 30 \\
\hline & Evening & 90 & 10 \\
\hline \multirow[t]{2}{*}{1995} & Day & 70 & 30 \\
\hline & Evening & 90 & 10 \\
\hline \multirow[t]{2}{*}{1996} & Day & 65 & 35 \\
\hline & Evening & 85 & 15 \\
\hline \multirow[t]{2}{*}{1997} & Day & 55 & 45 \\
\hline & Evening & 75 & 25 \\
\hline \multirow[t]{2}{*}{1998} & Day & 46,75 & 53,25 \\
\hline & Evening & 63,75 & 36,25 \\
\hline \multirow[t]{2}{*}{1999} & Day & 46 & 54 \\
\hline & Evening & 63 & 37 \\
\hline \multirow[t]{2}{*}{2000} & Day & 46 & 54 \\
\hline & Evening & 63 & 37 \\
\hline \multirow[t]{2}{*}{2001} & Day & 51 & 49 \\
\hline & Evening & 59 & 41 \\
\hline \multirow[t]{2}{*}{2002} & Day & 51 & 49 \\
\hline & Evening & 59 & 41 \\
\hline \multirow[t]{2}{*}{2003} & Day & 51 & 49 \\
\hline & Evening & 59 & 41 \\
\hline \multirow[t]{2}{*}{2004} & Day & 51 & 49 \\
\hline & Evening & 59 & 41 \\
\hline \multirow[t]{2}{*}{2005} & Day & 51 & 49 \\
\hline & Evening & 59 & 41 \\
\hline \multirow[t]{2}{*}{2006} & Day & 51 & 49 \\
\hline & Evening & 59 & 41 \\
\hline \multirow[t]{2}{*}{2007} & Day & 51 & 49 \\
\hline & Evening & 59 & 41 \\
\hline \multirow[t]{2}{*}{2008} & Day & 35 & 65 \\
\hline & Evening & 45 & 55 \\
\hline \multirow[t]{2}{*}{2009} & Day & 35 & 65 \\
\hline & Evening & 45 & 55 \\
\hline \multirow[t]{2}{*}{2010} & Day & 35 & 65 \\
\hline & Evening & 45 & 55 \\
\hline \multirow[t]{2}{*}{2011} & Day & 35 & 65 \\
\hline & Evening & 45 & 55 \\
\hline \multirow[t]{2}{*}{2012} & Day & 35 & 65 \\
\hline & Evening & 45 & 55 \\
\hline
\end{tabular}

References: Mamdani (2007: 217) ; Bursar office 


\section{Appendix C: Makerere Research and Development Budget, 2005-2009 (US\$)}

\begin{tabular}{|r|r|r|r|r|r|c|}
\hline Year & $\begin{array}{c}\text { Natural } \\
\text { sciences }\end{array}$ & $\begin{array}{c}\text { Engineering } \\
\text { and } \\
\text { technology }\end{array}$ & $\begin{array}{c}\text { Health } \\
\text { sciences }\end{array}$ & & Humanities & Total \\
\hline 2005 & 0 & 0 & 736,746 & $14,410,304$ & $4,310,133$ & $19,457,183$ \\
\hline 2006 & 202,154 & $1,807,557$ & 7359,473 & $14,212,214$ & $6,692,527$ & $30,273,925$ \\
\hline 2007 & 64,216 & $2,846,118$ & $11,330,270$ & $29,862,142$ & $4,353,128$ & $48,455,874$ \\
\hline 2008 & 39,294 & $4,649,320$ & $9,340,560$ & $25,297,779$ & $7,900,978$ & $47,227,930$ \\
\hline 2009 & 200,467 & $6,513,881$ & $5,772,139$ & $31,212,526$ & $18,000,570$ & $61,699,583$ \\
\hline
\end{tabular}

References: Republic of Uganda (2011: 55) 